\title{
KENALI EBOLA
}

\author{
Asri Hendrawati* \\ Departemen Biokimia Fakultas Kedokteran Universitas Islam Indonesia
}

Tahun 2014 merupakan tahun epidemi terbesar virus Ebola sepanjang sejarah. Pada Februari 2014, ditemukan lebih dari 150 orang terserang virus Ebola di Guinea dan Liberia, Afrika Barat. Kemudian kasus Ebola ditemukan meluas di negara Afrika lain. Angka kematian karena Ebola telah mencapai $90 \%$ penderita. ${ }^{1}$

Virus Ebola pertama kali ditemukan pada tahun 1976 di Sudan. Virus ini termasuk dalam famili Filoviridae, genus Ebolavirus. Terdapat 5 spesies Ebolavirus, 4 diantaranya menyebabkan penyakit pada manusia yaitu: Zaire ebolavirus, Sudan ebolavirus, Taï Forest ebolavirus, Côte d'Ivoire ebolavirus dan Bundibugyo ebolavirus. Virus jenis kelima adalah virus Ebola yang menyerang primata yaitu: Reston ebolavirus. ${ }^{2}$ Penyebaran dan penularan virus Ebola pada manusia masih belum diketahui tapi dicurigai merupakan penyakit yang ditularkan oleh hewan yaitu kelelawar. Penularan virus Ebola dari manusia ke manusia mudah terjadi. Menurut para ahli, virus Ebola dapat ditularkan melalui kontak dengan cairan tubuh penderita seperti darah, urin, cairan semen, air liur dan muntahan. Virus dapat masuk ke tubuh manusia melalui kulit atau mukosa yang tidak intak. ${ }^{3}$

Penyakit yang ditimbulkan virus Ebola disebut dengan Ebola hemorrhagic fever. Masa inkubasinya sekitar 6-8 hari. Manifestasi klinis yang terjadi adalah demam tinggi mencapai $40^{\circ} \mathrm{C}$, nyeri kepala hebat, nyeri otot, muntah, diare, nyeri perut dan diikuti perdarahan spontan yang masif. ${ }^{4}$ Diagnosis Ebola pada awal penyakit sulit ditegakkan jika hanya berdasarkan gejala klinis. Jika ada kecurigaan kontak dengan penderita Ebola, perlu dilakukan pemeriksaan seperti ELISA, PCR, isolasi virus atau imunohistokimia. ${ }^{5}$

Obat antivirus maupun vaksin untuk penyakit Ebola belum ditemukan hingga saat ini. Terapi yang dapat diberikan kepada penderitanya hanya sebatas terapi suportif seperti pemberian oksigen, cairan intravena dan obat-obat simtomatik. ${ }^{6}$ Karena penularan dan penyebarannya sangat cepat dan prognosisnya buruk, penyakit Ebola harus segera dicegah. 
Dahsyatnya wabah Ebola di benua Afrika saat ini menjadi perhatian dunia termasuk Indonesia. Bahkan, pemerintah Arab Saudi telah membatalkan kuota umroh dan haji tahun 2014 bagi negara-negara Afrika yang terserang wabah virus Ebola demi mencegah penyebarannya. Diharapkan negara-negara di luar benua Afrika termasuk Indonesia dapat melakukan upaya-upaya untuk mencegah penyebaran virus Ebola masuk ke negaranya.

\section{DAFTAR PUSTAKA}

1. European Centre for Disease Prevention and Control. Outbreak of Ebola virus disease in West Africa. Stockholm: ECDC; 2014.

2. Li YH, Chen SP. Evolutionary history of Ebola virus. Epidemiol Infect. 2013;16:1-8.

3. Bausch DG, Towner JS, Dowell SF, Kaducu F, Lukwiya M, Sanchez A, et al. Assessment of the risk of Ebola virus transmission from bodily fluids and fomites. J Infect Dis. 2007;196:S142-7.

4. Roddy P, Howard N, Van Kerkhove MD, Lutwama J, Wamala J, Yoti Z, et al. Clinical manifestations and case management of Ebola haemorrhagic fever caused by a newly identified virus strain, Bundibugyo, Uganda, 2007-2008. PLoS One 2012;7(12):e52986.

5. Colebunders R, Borchert M. Ebola haemorrhagic fever--a review. J Infect. 2000;40(1):16-20.

6. Clark DV, Jahrling PB, Lawler JV. Clinical management of filovirus-infected patients. Viruses 2012;4(9):1668-86. 